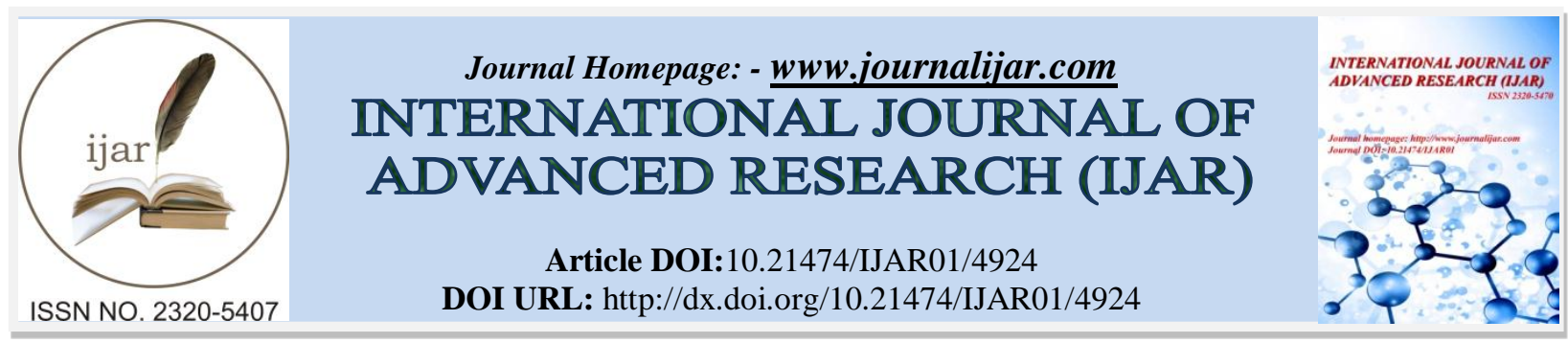

RESEARCH ARTICLE

\title{
A STUDY OF JOB SATISFACTION OF TEACHERS WORKING IN SELF-FINANCED TEACHER EDUCATION COLLEGES.
}

Dr. Umesh Chandra Kapri.

Associate Professor, Gold Field College of Education, Faridabad.

\section{Manuscript Info}

\section{Manuscript History}

Received: 22 May 2017

Final Accepted: 24 June 2017

Published: July 2017

Key words:-

Job Satisfaction, Teacher Education

Self-Financed Colleges.

\section{Abstract}

Satisfaction is the biggest thing in our life. The person, who is satisfied with his/her life, is a successful person. Satisfaction does not mean to have too much money or to have too much material things but it deals with feeling of harmony with life. Job satisfaction is the state of feelings towards the job undertaken by an employee either positively or negatively. Job Satisfaction is often seen as involving Teachers with salary, promotion in job, school environment and coordination and co-operation among teachers and among teachers and students. Descriptive survey method was used to conduct a pilot study to determine the level of job satisfaction amongst teachers working at self-financed Teacher Education Colleges located at Faridabad district of Haryana state in India. The population of the present study comprised of the 120 Teachers working in self-financed Teacher Education Colleges located at Faridabad district. Meera Dixit's Job Satisfaction Questionnaire was used to collect data. The findings of the study show that majority of teachers of Self-financed Teacher Education Colleges were found at average and at below average level of job satisfaction. A significant difference was found between the male and the female teachers of self-financed Teacher Education Colleges with respect to their job satisfaction. The female teachers of self-financed Teacher Education Colleges were found to be more satisfied with their jobs in comparison to their counterpart, the male teachers of self-financed Teacher Education Colleges.

Copy Right, IJAR, 2017,. All rights reserved.

\section{Introduction:-}

The most important and effective human factor in any educational system is the teacher. It is the teacher who refines the instincts and modifies behaviour of students and makes them socially acceptable, inculcates values, inspires and develops capabilities to their fullest and best possible ways, so that they may be of best use to themselves and to the society, to the nation and to the mankind as a whole. But at the same time it is also true that the development of science and technology and socio-economic transformation make society and human life complex and dynamic, where the teachers have to face hard life to act satisfactorily with their daily life and work. Teachers are arguably the most important group of professionals for our nation's future. Therefore, it is disturbing that many of today's teachers are dissatisfied with their jobs. A teacher, who is happy with his job, plays a pivotal role in the upliftment of society. Well-satisfied teacher can contribute a lot to the well-being of his/her pupils. An 
unsatisfied teacher can become irritable and may create tensions which can have negative influence on the students' learning process. Job satisfaction implies the overall adjustment to work situation.

The Higher Education Commission (1953) defined that "we are however, convinced that most important factor in the contemplated educational reconstruction is the teacher - his quality, his educational qualifications, his professional training and the place he occupies in the school as well as in the community. The reputation of a school and its influence on the life of the community invariably depend on the kind of teachers working in it.' A lot of research efforts have been directed on teacher effectiveness and teaching competency but unfortunately much attention of research is not drawn to correlate teaching competency in relation to Teacher Job Satisfaction. Rao, R.B. (1989) says that, "the quality or effectiveness of teachers is considered to be associated with his satisfaction towards his profession, his satisfaction with his values".

\section{Job Satisfaction:-}

Job satisfaction is a combination of psychological, physiological and environmental circumstances that causes a person to say that he/she is satisfied with his/her job. It is the result of various attitudes possessed by an employee towards his/her job. These attitudes may be related to job factors such as wage, job security, job environment, nature of work, opportunity for promotion, prompt removal of grievance, opportunity for participation in decision making and other fringe benefits. Job satisfaction may thus be defined as an attitude which results from a balancing and summation of many specific likes and dislikes experienced by an employee in the performance of his job (Bullock, 1952). Job satisfaction refers to one's job, his general adjustment and social relationship in and outside his job. The satisfaction and dissatisfaction with one's job depends upon the positive or negative evaluation of one's own success or failure in the realization of personal goals.

The term "Job Satisfaction" was first described by Hoppock (1935) who observed that Job Satisfaction is a combination of psychological, physiological and environmental circumstances that cause a person to say "I am satisfied with my job". Job Satisfaction is the extent to which people like (satisfaction) or dislike (dissatisfaction) their jobs (Spector 1997). However a more direct description is provided by Saiyadain (2007) who defines Job Satisfaction as the end state of feeling, the feeling that is experienced after a task is accomplished. This feeling could be negative or positive depending on the outcome of the task undertaken. Job satisfaction is very important for the general mental health of an individual. Teachers play a significant role in the field of education who deal with all the policies and programmes of education. Thus job satisfaction of teachers is of crucial importance. This relates to his identification with the profession and his/her willingness to be effective. Job satisfaction not only increases efficiency but also it provides intrinsic motivation for work. Job satisfaction is necessary for the development of any educational organization because directly or indirectly it influence attitude, morale, and absenteeism and production level of teachers. Several studies suggest that job satisfaction of teachers is positively related to their attitude and effectiveness in teaching.

\section{Factors that Influence Job Satisfaction:-}

Job satisfaction plays a pivotal role making a teacher more effective and satisfied. There may be various factors which influence teachers' job satisfaction. A few of them are as given below;

Environmental Factors: College environment is one of the most important factors which influence teacher job satisfaction.

Superior-subordinate Communication:- Communication behavior such as facial expression, eye contact, vocal expression, and body movement is crucial to the superior-subordinate relationship.

Strategic Employee Recognition:- A Watson Wyatt study identified a positive outcome between a collegial and flexible work environment and an increase in shareholder value.

Individual Factors: Teachers' emotion, personality, subject knowledge and psychological factors include individual factors.

Emotion:- Mood and emotions are the affective elements of job satisfaction.

Genetics:- It is said that teachers are born. It is true that genetics influence a variety of individual differences. 
Personality:- Some researchers suggest an association between personality and job satisfaction. Individual with high in negative affectivity are more prone to experience less job satisfaction. Those high in positive affectivity are more prone to be satisfied in most dimensions of their lives, including their jobs.

Psychological factors:- An individual's psychological functioning are related to their work, family, community etc. Therefore, teachers' Psychological well-being is mandatory which affects his/her overall effectiveness.

Salary:- Low or poor salary structure causes dissatisfaction among teachers in India.

Academic Qualification: Academic fitness is important in teaching profession. To be an effective teacher one must be academically sound.

Physical Environment:- Physical environment such as school building, class rooms, furniture, teachers' room, toilets, playground, computer facilities, telephone and location of the schools etc. are some common factors which affect teachers' job satisfaction.

Social Environment:- The social environment covers family support to the teachers, teacher - student relationship, interpersonal relationship among the colleagues, head teacher - assistant teachers' relationship, and teacher guardian relationship, attitude of the school managing committee (SMC) as well as the local elites.

Career Prospect:- Career starts with recruitment and selection and then goes with promotion, training and transfer as well as placement. Their satisfaction and dissatisfaction depends upon the factors through which a teacher can reach to the ultimate goals of the job.

Supervision:- Supervision implies to supervise teachers by the head teacher in a school. It plays an important role in context of job satisfaction.

Social Status:- In India teaching is one of the honorable professions. In the society every one respects a teacher and the teacher should also maintain the dignity of his/her job.

Job Security:-This factor is most important for all the persons doing job. If teachers think that their job is secure, they feel that they are most satisfied.

\section{Need and Significance of the Study:-}

Educational institutions are inseparable part of the development of a country and teachers are the active participants of improving quality of education so teachers must be satisfied with their profession. The satisfaction can make them devoted and committed to their responsibilities. But such satisfaction is hindered by some organizational as well as cultural phenomena. The financial benefits, the rewards or punishment system, in-group relationship, the culture of the organization and society etc. contribute to affecting their satisfaction. Job satisfaction is the state of feelings towards the job undertaken by an employee either positively or negatively. Job satisfaction is a pleasurable emotional state resulting from the appraisal of one's job. A teacher has positive attitude towards teaching if he/she is satisfied with his/her job. Job satisfaction is very important for the general mental health of an individual. Job satisfaction not only increases efficiency but also provides intrinsic motivation for work. Several studies suggest that job satisfaction of teachers is positively related with their effectiveness.

In India Teacher Education Colleges are much concerned with preparation of students to be prospective effective, competent and skilled teachers. They are also concerned about quality of life. They teach the students with much care. Even they expect harmonious relation among their colleagues. Today majority of female teachers are working shoulder to shoulder with male teachers in schools and colleges, so they must have mutual understanding. Job satisfaction is not only good for employees but employers too. It increases an individual's efficiency and productivity.

At present job satisfaction has been an important issue. The self-financed Teacher Education Colleges of India are highly concerned to education of prospective teachers. Teachers are interested to work in the organization or institution where they get more satisfaction. Opening, affiliation and recognisation of Teacher Education Colleges in India has been given much importance in past decade but the development of teacher educators and their job 
satisfaction is not given attention. This study may help to divert the attention of government, stake holders and the authorities to that direction of job satisfaction of teachers working in self-financed Teacher Education Colleges. Hence present problem is under taken to study job satisfaction of teachers working in self-financed Teacher Education Colleges of Faridabad district of Haryana.

\section{Statement of the Problem:-}

The research problem is entitled as, "A Study of Job Satisfaction of Teachers Working in Self-Financed Teacher Education Colleges".

\section{Objectives of the Research:-}

1. To study the level of job satisfaction of teachers working in self-financed Teacher Education Colleges.

2. To study the level of job satisfaction of male teachers working in self-financed Teacher Education Colleges.

3. To study the level of job satisfaction of female teachers working in self-financed Teacher Education Colleges.

4. To study the difference between job satisfactions of male and female teachers working in self-financed Teacher Education Colleges.

\section{Hypotheses:-}

There is no significance difference between job satisfaction of male and female teachers working in self-financed Teacher Education Colleges.

\section{Methodology:-}

The study was designed of a descriptive survey in order to know job satisfaction of teachers working in selffinanced Teacher Education Colleges. It is correlational in nature. Descriptive method attempts to describe and interpret what exists at present in the form of conditions, practices, processes, trends, effects, attitudes, beliefs etc.

\section{Population and Sample:-}

The population for the present study comprised of the teachers working in self-financed Teacher Education Colleges located at Faridabad district of Haryana. 120 Teachers working in self-financed Teacher Education Colleges included in sample, out of which there were 60 male and 60 female teachers selected randomly from 10 Teacher Education Colleges located at Faridabad district of Haryana state.

\section{Tools Used:-}

Meera Dixit's Job Satisfaction Questionnaire was used to collect data for the present study.

\section{Statistical Techniques Used:-}

Statistical Techniques such as mean, standard deviation, Z- scores and t- test were used for analysis and interpretation of the collected data.

\section{Delimitations of the Study:-}

1. The study was delimited to the teachers working in self-financed Teacher Education Colleges located at Faridabad district of Haryana.

2. Only 120 teachers working at Self-financed Teacher Education Colleges of Faridabad were taken for the study.

\section{Analysis of the data:-}

To measure the level of Job Satisfaction of teachers working in Self-financed Teacher Education Colleges 'Job Satisfaction Scale, developed by Dr. (Mrs.) Meera Dixit was administered on the sample. The data were tabulated and converted into standard scores. The analysis and interpretation of the data obtained by administering 'Job Satisfaction Scale' are as given below; 
Table 1:- Level of Job Satisfaction of Teachers of Self-Financed Teacher Education Colleges

\begin{tabular}{|l|l|l|l|l|}
\hline S.N. & Range of Z-scores & Grade & Level of Job Satisfaction & Number of Teachers \\
\hline 1. & $+2.01 \&$ Above & A & Extremely High & 8 \\
\hline 2. & +1.25 to +2.00 & B & High & 11 \\
\hline 3. & +0.51 to +1.25 & C & Above average & 16 \\
\hline 4. & -0.50 to +0.50 & D & Average & 36 \\
\hline 5. & -0.51 to -1.25 & E & Below average & 32 \\
\hline 6. & -1.25 to -2.00 & F & Low & 13 \\
\hline 7. & -2.01 to and below & G & Extremely Low & 4 \\
\hline
\end{tabular}

The table 1 shows the number of teachers of self-financed Teacher Education Colleges under various levels of job satisfaction scale. On analyzing the data of level of job satisfaction of 120 teachers of self-financed Teacher Education Colleges, it was concluded that 8 teachers of self-financed Teacher Education Colleges were found to be at extremely high level of job satisfaction while 11 teachers were found under high level, 16 teachers were under above average level, 36 teachers at average level, 32 teachers at below average level, 13 teachers at low level and only 4 teachers of self-financed Teacher Education Colleges were found to be at extremely low level of job satisfaction. Most of the teachers of self-financed Teacher Education Colleges were found at average and below average level of job satisfaction. Only 4 teachers of self-financed Teacher Education Colleges were found at extremely low level of job satisfaction.

The table 2, given below shows the t-ratio between the scores of job satisfaction of male and female teachers of Selffinanced Teacher Education Colleges.

Table 2:- Comparison of Scores of Job Satisfaction between Male and Female Teachers of Self-financed Teacher Education Colleges

\begin{tabular}{|l|l|l|l|l|l|}
\hline Categories & $\mathrm{N}$ & Mean & Std. Deviation & t- ratio & Remarks \\
\hline Male Teachers & 60 & 163.5 & 34.26 & 4.53 & Significant \\
\cline { 1 - 4 } Female Teachers & 60 & 193.2 & 37.54 & & \\
\hline
\end{tabular}

The calculated t-ratio between the male and the female teachers of Self-financed Teacher Education Colleges with respect to their Job Satisfaction was found to be 4.53 which is greater than 1.96 significant at 0.05 level and 2.59 significant at 0.01 level of significance. So, the hypothesis of the study that there is no significant difference of job satisfaction between male and female teachers working in Self-financed Teacher Education Colleges is rejected. A significant difference of level of Job Satisfaction was observed between male and female teachers working at Selffinanced Teacher Education Colleges. The Job Satisfaction of female teachers working at Self-financed Teacher Education Colleges was found to be higher in comparison to their male counterpart.

\section{Major findings of the study:-}

1. Majority of teachers of Self-financed Teacher Education Colleges were found at average and at below average level of Job Satisfaction.

2. Least number of teachers of Self-financed Teacher Education Colleges were found at Extremely High and at Extremely low level of Job Satisfaction.

3. The male and the female teachers of Self-financed Teacher Education Colleges differ significantly with respect to their Job Satisfaction.

4. The result shows that the female teachers of Self-financed Teacher Education Colleges were found to be more satisfied with their jobs than the male teachers of Self-financed Teacher Education Colleges.

\section{Conclusion:-}

There may be various factors which affect job satisfaction of teachers such as workload, pay, promotion, supervision and their Salary. Job satisfaction is found directly linked with financial aspect. The higher such outcome is, the higher the employee is satisfied with that job. The teachers were found dissatisfied because of low salary. According to Herzberg's two factor theory, salary is a hygiene factor which causes dissatisfaction. If salary is lower the employees become dissatisfied with their jobs. Thus the low or poor salary structure causes dissatisfied almost all 
the teachers in Higher education in India. Physical environment such as infrastructure of the college building, class rooms, furniture, teachers' room, toilets, playground, computer facilities, telephone, fax, communication and location of the colleges etc. also affect the job satisfaction of teachers. The teachers of self-financed Teacher Education Colleges were found dissatisfied due to poor physical environment, promotion policy and unfavorable working condition. It is the desire of the society that the Teachers of Self-financed Teacher Education Colleges must be given such input those can make them happy as well as satisfied.

\section{Educational implications:-}

1. Satisfaction from the job is necessary for full devotion and commitment of teachers towards their colleges. Even the best educational system is bound to fail in the absence of competent and satisfied teachers. Unless the teacher is satisfied with his/her job, he/she cannot deliver the good properly.

2. The teachers need to be empowered by giving autonomy. The college authorities can organize special welfare programs for teachers' well-being and positive changes in their level of satisfaction.

3. The teachers having different levels of job satisfaction may also require different motivational strategies such as bonuses and other type of rewards.

4. Necessary efforts from concerned management committees are required to introduce new schemes and modifications of the existing institutional plans and policies.

5. A clear system of motivation, supported and sustained by an effective system of incentives has to be developed to reduce dissatisfaction of the teachers.

6. Arrangement to be made at the institutional level for job enrichment, job variation among the teachers in academic and related activities to break the monotony of work and to bring innovation.

\section{Suggestions for further research:-}

1. The similar study may be conducted to see the adjustment level of various subject teachers.

2. The study needs to be replicated on a wider sample of waste area so that the results are better confirmed.

3. The current study was the adherence for measuring the job satisfaction of teachers of self -financed Teacher Education Colleges and future research may be used to add with several dimensions for evaluating job satisfaction of teachers.

4. The present investigation is related to self-financed teachers. It could be extended to secondary as well as college and even at university level.

\section{References and bibliography:-}

1. Directorate of Higher Education (DPE) India (2004): Higher Education Statistics in India.

2. Dixit, M. (1993). Job Satisfaction Scale. Agra: National Psychological Corporation.

3. Education and job satisfaction, 1962-1977. The Vocational Guidance Quarterly, 29(2), 100-111.

4. Gupta, M., \& Jain, R. (2003). Job Satisfaction of Nursery School Teachers Working in Delhi. Indian Psychological Review, 61, 49-56.

5. Herzberg, Fredrick, et.al (1959): The Motivation to Work, p.ix

6. Hoppock, R., (1935): Job Satisfaction, Harper and Brothers, New York, p. 47.

7. Kaur, G., \& Sidana, J. J. (2011). Job satisfaction of teachers of Punjab with respect to area, gender and type of institution, Edutracks, 10(11), 27-35.

8. Menon, M. E., Athanasoula-Reppa, A. (2011). Job satisfaction among teachers: The role of gender and experience, School Leadership and Management, 31(5), 435-450.

9. Rawat, P.L. History of Indian Education, Ram Prasad and Sons. Agra - 3.

10. Rosnowski, M., \& Hulin, C. (1992).The Scientific Merit of Valid Measures of General Constructs with Special Reference to Job Satisfaction jnd Job Withdrawal.

11. Saiyadain, M (2007), Human Resource Management, New Delhi, Tata McGraw Hill.

12. Smith, P., (1961): Job Satisfaction and related factors. Journal of Applied Psychology, Vol 64, 82-87. 